\title{
У Lääkäri-potilas -suhteen harjoittelua - lääkäriopiskelijoiden tulkinnat potilastapauksesta koulutuksen eri vaiheissa
}

\begin{abstract}
Tässä laadullisessa pitkittäistutkimuksessa analysoidaan, miten lääkäriopiskelijat rakentavat lääkäri-potilas suhdetta ja tulkitsevat samaa potilastapausta koulutuksen eri vaiheissa. Tutkimus on osa LeMEx (Learning Medical Expertise) -tutkimusprojektia, jonka aineisto kerättiin vuosina 2006-2012. Tutkimuksessa seurattiin samoja lääkäriopiskelijoita koko heidän koulutuksensa ajan. Tutkimusaineisto muodostui vuonna 2006 opintonsa aloittaneiden lääkäriopiskelijoiden $(\mathrm{N}=137)$ kirjallisista vastauksista. Tutkimusaineisto kerättiin kyselylomakkeella, jossa opiskelijaa pyydettiin pohtimaan potilastapauskuvausta. Vastaukset analysoitiin induktiivisella sisällönanalyysilla. Koulutuksen myötä lääkäriopiskelijoiden vuorovaikutustaidot ammatillistuvat ja suhtautumistapa potilaaseen ja omaiseen muuttuu laadultaan. Koulutuksen lopussa lääkäriopiskelijoiden empaattisuus vähenee ja omaista kohtaan välittyy eniten negatiivisia ilmauksia. Vastaavasti tuolloin lääkäriopiskelijat osaavat huolehtia yhteistyön jatkosta ja pyrkivät pääsemään yhteisymmärrykseen potilaan kanssa.
\end{abstract}

\section{Asiasanat: lääkäri-potilas-suhde, lääkärikoulutus, lääkäriopiskelijat, potilaan kohtaaminen}

\section{MARI SUNDSTRÖM, HEIKKI SILVENNOINEN, PEKKA KÄÄPÄ, OLLI VAINIO}

\section{JOHDANTO}

Lääketieteellisen tiedon ja kliinisten taitojen hallitseminen on lääkärityön tärkein edellytys. Potilaan kohtaaminen taas on lääkärityön ydintapahtuma, jolle potilaan ja lääkärin yhteistyö luo perustan. Vuorovaikutus on jatkuva prosessi, jossa kumpikin osapuoli on aktiivinen toimija samanaikaisesti. Viestiessään keskenään osapuolet puhuvat, kuuntelevat ja katselevat; tekstit, sanat ja eleet kuljettavat viestejä joiden laatu vaihtelee eri tilanteissa. (1-3.) Vaikka hoitaminen onkin aina yhteistyötä, lääkärin ja potilaan vuorovaikutus rakentuu epäsymmetriselle professionaaliselle viestintäsuhteelle, jossa vain toisella on tunnustettu asiantuntijan status (2). Osapuolilla on erilainen tieto ja osaaminen, eri näkökulma vuo- rovaikutukseen sekä eri oikeudet ja velvollisuudet osallistua vuorovaikutukseen.

Vuorovaikutuksen laatu ja potilaan osallistuminen ovat yhteydessä potilaan kokemaan luottamukseen ja tyytyväisyyteen sekä hoidon vaikuttavuuteen. Potilas on kuitenkin omaa elämäänsä ja elämäntilannettaan koskevan kokemuksen paras asiantuntija. Keskustelun avulla lääkäri saa potilaalta tärkeää informaatiota. Lääkärin ja potilaan välisellä vuorovaikutuksella on keskeinen rooli hoidon onnistumisessa ja potilaan sitoutumisessa omaan hoitoonsa. Esimerkiksi lääkehoidon onnistuminen vaatii potilaan motivoimista. Toimiva vuorovaikutus on luottamuksellisen hoitosuhteen perusta. Luottamukselle rakentuva lääkäri-potilas-suhde auttaa po- 
tilasta osallistumaan päätöksiin ja lisää potilaan tyytyväisyyttä. Se vähentää sairastumisen kuormitusta ja edistää potilaan paranemista. (4-13.) Vuorovaikutus muodostaa viitekehyksen, jonka puitteissa ammattilainen käyttää alansa substanssitietoa. Lääkärin ja potilaan vuorovaikutuksessa saavutetaan työn tavoitteet ja tulokset, tehdään diagnoosi, ratkaistaan potilaan ongelma ja keskustellaan vaihtoehdoista. Näin vuorovaikutuksesta tulee ongelmanratkaisun keskeinen viitekehys. (2.)

Lääkärikoulutuksen yksi tavoite on auttaa opiskelijoita kohtaamaan ja ymmärtämään potilaita, mutta vuorovaikutusopintoja koulutukseen sisällytettiin vasta 1990 -luvulla $(1,14)$. Nykyisin vuorovaikutusopinnot ovat vakiintuneet osaksi lääkärin peruskoulutusta. Esimerkiksi Yhdysvalloissa ja Isossa-Britanniassa vuorovaikutusopintoihin liittyvää tutkimusta tehty verraten paljon (10,11,15-23), mutta Suomessa erityisesti pitkittäistutkimusta aiheesta on niukasti $(24,25)$.

Lääketieteen kehitys ja elintason nousu sekä väestön tarpeiden ja odotusten muutokset ovat viime vuosikymmeninä olleet merkittäviä. Vuoteen 2013 saakka maamme viiteen lääketieteen opetusta antavaan yliopistoon otettiin vuosittain noin 600 opiskelijaa, ja määrä nostettiin 750 opiskelijaan vuonna 2016. Opetus- ja kulttuuriministeriön kehittämissuunnitelmassa 2011-2016 lääketieteen koulutukselle osoitettiin merkittävää aloituspaikkojen lisäystä, mikä Turun ja Oulun yliopistoissa on tarkoittanut yli 30 lisäpaikkaa (26). Tämä on haaste vuorovaikutusopintojen kannalta. Opetuksen korkean laadun tulee säilyä, eikä vuorovaikutustaitojen oppimisen kannalta merkittävä pienryhmäkoko saisi kasvaa. Tällä hetkellä lääkärikoulutustaan suorittavat opiskelijat tulevat olemaan työelämässä ainakin 2050-luvulle saakka. On aiheellista kysyä, antaako nykyinen koulutus riittävät vuorovaikutustaidot lääkärin työhön vai pitäisikö koulutusta joltain osin muuttaa.

Lääkärikoulutuksen kehittämisen kannalta olisi tärkeää saada tutkittua tietoa opiskelijoiden vuorovaikutustaitojen kehittymistä. Koko opiskeluajan kattavaan pitkittäistutkimukseen pohjautuvaa tietoa opiskelijoiden vuorovaikutustaidoista potilaan kohtaamisessa ei ole. Tämän pitkittäistutkimuksen tarkoituksena onkin tarkastella koulutuksen koko keston ajan, miten opiskelijat rakentavat lääkäri- potilas suhdetta.
Kysymme artikkelissa: miten lääkäriopiskelijat tulkitsevat samaa potilastapausta ja millaisia muutoksia lääkäri-potilas suhteen ilmauksissa on havaittavissa koulutuksen eri vaiheissa?

\section{VUOROVAIKUTUSOPINNOT LÄÄKÄRIKOULUTUKSESSA}

Osaamisperusteinen koulutus (Competence

Based Education) on lääketieteen opettamisessa hallitseva tapa maailmalla. Osaamistavoitteina ilmaistut kompetenssit määritellään niiksi tiedoiksi, taidoiksi ja asenteiksi, jotka koulutuksen jälkeen työelämään siirtyvän lääkärin tulisi hallita. (27.) Vaadittavan osaamisen osa-alueet ja siihen sisältyvät taidot vaihtelevat maittain ja organisaatioittain. Lääketieteen vuorovaikutuskoulutukselle on myös olemassa erilaisia suosituksia. IsossaBritanniassa General Medical Council, Euroopassa European Federation of Internal Medicine, Yhdysvalloissa Accreditation Council for Graduate Medical Education ja Kanadassa Royal Collage of Physicians and Surgeons of Canada esittävät suosituksia opetussuunnitelmalle ja korostavat vuorovaikutustaitojen merkitystä lääkärin työssä (25). Tämän lisäksi lääketieteen vuorovaikutuskoulutuksen tueksi löytyy monia tutkimukseen perustuvia malleja, joissa kuvataan lääkäri-potilasvuorovaikutuksen keskeiset osa-alueet (esim. The Calgary-Cambridge Observation (28), The SEGUE framework for teaching and assessing communication skills (29) ja Beyer-Fetzer Kalamazoo Consensus Statement (30)). Tiedekunnilla on lukuisia eri tapoja opettaa ja arvioida vuorovaikutustaitoja $(10,31)$.

Lääketieteen asiantuntijoille ja opiskelijoille suunnattua vuorovaikutuskoulutusta on kansainvälisesti tutkittu ja arvioitu runsaasti (25). Tutkimuksissa korostetaan, että vuorovaikutustaitojen opetuksen ja kehittämisen tulee olla tietoista ja harkiten suunniteltua toimintaa, jossa kliinisten taitojen oppimisen mukana vuorovaikutustaitoja tukevat opinnot syvenevät systemaattisesti. Tutkimustulokset osoittavat, että vuorovaikutuskoulutukseen osallistuneet lääketieteen opiskelijat tai asiantuntijat ovat oppineet vuorovaikutusosaamista ja heidän vuorovaikutustaitonsa ovat kohentuneet koulutuksen myötä. (10,11,15-25.) Vuorovaikutusopintojen sisällyttäminen lääketieteen perustutkintoon ei kuitenkaan ole ongelmatonta. Ongelmia aiheuttavat ajan puute jo muutenkin täydessä opetussuunnitelmassa ja opetushenkilökunnan ristiriitaiset 
asenteet vuorovaikutusopintoja kohtaan $(32,33)$. Lääkäri-potilasvuorovaikutustutkimuksen tulosten soveltaminen opetuksen tarpeita vastaavasti ja oppimismenetelmien kehittäminen on osoittautunut vaikeaksi tehtäväksi (28).

Vuorovaikutustaitojen opettamisessa käytetään menetelmiä, joissa keskeistä on oppilaan oma kokemus ja reflektio (1). Opettajakeskeisen luennon sijasta tai sen rinnalla käytetään opiskelijakeskeisiä oppimismenetelmiä. Taustalla on konstruktivistinen oppimiskäsitys, jonka mukaan hyvän oppimisen edellytyksenä on opiskelijan oma sitoutuminen tiedon rakentamiseen. Siinä opettaja ei vain siirrä tietoa omasta päästään opiskelijan päähän, vaan oppija nähdään itse aktiivisesti tietoa ja ymmärrystään rakentavaksi toimijaksi. (34-36.) Opiskelijakeskeisillä menetelmillä voidaan saada aikaan muutoksia opiskelijoiden asenteissa ja kehittää ymmärryksen lisäksi heidän viestintästrategioitaan (19).

Vuorovaikutusopinnot etenevät potilashaastattelun perusteista haasteellisempiin aiheisiin, jolloin aiemmin opittu syvenee ja liittyy muuhun opittuun (24). Menetelminä käytetään portfolioita, vertaisarviointeja, ulkopuolisia arvioijia ja simulaatioita Anne-nukesta näyttelijäpotilaisiin. Uusia menetelmiä ovat roolipelit ja draamakasvatuksen menetelmät, kuten improvisaatio, pienoisnäytelmät, sairautta kuvaavat näytelmät, työpajateatteri, forumteatteri tai prosessidraama (25). Esimerkiksi potilashaastatteluharjoituksissa simuloituina potilaina toimivat toiset opiskelijat, näyttelijät tai, kuten Turussa, saariston ruotsinkieliset eläkeläiset. Myös potilasvastaanottojen videointia ja arviointia on pidetty toimivana oppimismenetelmänä. Paljon huomiota ovat myös saaneet 360 asteen arvioinnit, joissa palautetta kerätään kollegojen lisäksi muilta työntekijöiltä ja potilailta $(1,19,24,25)$.

Pääosin vuorovaikutusta opetetaan kolmantena lukuvuotena, kun opiskelijat siirtyvät kliiniseen vaiheeseen. Käytössä on myös miniCEX (the mini-Clinical Evaluation Exercise) ja kliinistä potilaan tutkimustilanteen arviointia ja vuorovaikutus- ja ongelmanratkaisutaitoja mittaava OSCE-tentti (Objective Structured Clinical Examination). Opettajatuutorointi- ja mentoriohjelmat ovat olleet käytössä useissa lääkärikoulutusyksiköissä USA:ssa ja Euroopassa 1990-luvulta lähtien (37,38). Turun yliopistossa opettajatuutorointitoiminta alkoi nykyisessä muodossaan vuonna 2005. Sen on todettu edistävän lääkäriopiskelijoiden arvojen ja asenteiden sekä ammatillisten teemojen pohdintaa. Tällaista reflektointia pidetään tärkeänä tukena lääkäriopiskelijoiden ammatilliselle ja henkilökohtaiselle kehitykselle (39).

\section{VUOROVAIKUTUSTAITOJEN MERKITYS POTILAAN KOHTAAMISESSA}

Jokainen vastaanotolle tuleva potilas on ainutlaatuinen, ja samakin sairaus ilmenee eri tavalla eri ihmisissä. Yhä useammat perusterveydenhuollon potilaat ovat moniongelmaisia, potilaiden elinikä on noussut, he tulevat eri kulttuureista, eikä lääkärillä ja potilaalla aina ole yhteistä kieltä (40). Potilaista on tullut entistä vaativampia asiakkaita, ja he kiinnittävät enemmän huomiota palvelujen laatutasoon myös terveydenhoidossa. Potilaat tietävät omista sairauksistaan yhä enemmän, ja lääkärin on haettava yhteistyössä potilaan kanssa ratkaisua tämän yksilöllisesti ilmenevään terveysongelmaan. Koulutetulla hoitohenkilökunnalla ei ole enää monopolia lääketieteelliseen tietoon. Terveydestään kiinnostuneet ja terveydentilaansa arvioivat potilaat ovat hyviä yhteistyökumppaneita terveysongelman ratkaisemisessa, ja lääkäriopiskelijan olisikin opittava vastaanottotilanteessa hyödyntämään potilaiden lisääntynyttä tietämystä ja perehtyneisyyttä terveydentilaansa. Potilaalla on myös valta itseään koskevassa päätöksenteossa. Laki potilaan asemasta ja oikeuksista (785/1992) velvoittaa lääkärin tekemään potilasta koskevat hoitopäätökset yhteisymmärryksessä potilaan kanssa. Hyvät vuorovaikutustaidot mahdollistavat korkeatasoisen hoidollisen vuorovaikutuksen sekä lisäävät asiantuntijan pätevyyttä. $(2,24,25$. $)$

Tutkimukset osoittavat, että tunteista ja odotuksista keskusteleminen huojentaa potilasta. Katseilla ja eleillä, sanoilla ja sanomatta jättämisillä on potilaalle merkitys. Potilaalle kuulluksi, ymmärretyksi ja vastatuksi tuleminen ovat tärkeä osa hoitoa (41). Huonot kohtaamiset jäävät voimakkaasti mieleen, mutta luottamuksellinen suhde kestää jopa hoitovirheitä, kiirettä tai hetkellistä huomiotta jättämistä. (4-7.)

\section{AINEISTOT JA MENETELMÄT}

Tutkimus on osa Turun ja Oulun yliopiston lääketieteellisen tiedekunnan LeMEx (Learning Medical Expertise) -tutkimusprojektia. Hankkeen 
kuusi vuotta kestäneen kohorttitutkimuksen aineisto kerättiin vuosina 2006-2012. Tutkimuksessa seurattiin samaa opiskelijajoukkoa koko koulutuksen ajan. Opiskelijat osallistuivat joka vuosi kyselytutkimukseen. Yhtenä tehtävänä kyselylomakkeessa oli potilastapauskuvaus, johon opiskelijoita pyydettiin vastaamaan. Lääkäriopiskelijalle esitetty tehtävä on seuraava:

Terveysaseman vastaanotolle saapuu tyttären saattamana yksin asuva 78-vuotias naispotilas. Tyttären mielestä äidille on viime aikoina ilmaantunut muistamattomuutta, sekavuutta ja huimausta lisääntyvässä määrin. Tytär toivoo äidin saavan lähetteen keskussairaalaan tutkimuksia varten. Pohdi tilannetta ja kerro mitä ajatuksia se sinussa herättää.

Lääkäriopiskelijan saama informaatio potilastapausta kuvaavassa tehtävässä on verraten vähäinen. Se tarjoaa lähtökohdan, josta lääkäriopiskelijan on ryhdyttävä itse rakentamaan mielessään vuorovaikutus- ja hoitotilannetta. Tilanteessa on kolme henkilöä: potilas, tämän saattaja ja lääkäri. Kirjallinen tehtävä kertoo potilaasta neljä faktaa: sukupuolen (nainen), iän (vanha) ja asumisolot (asuu yksin) sekä sen, että potilaalla ja saattajalla on läheinen sukulaisuussuhde (äiti ja tytär). Lääkäri saa muun alkuinformaation potilaasta tämän saattajalta (potilaan oireet). Saattaja kuvaa lääkärille potilaan huolestuttavaa tilaa ja esittää toivomuksen potilaan puolesta (lähete tutkimuksia varten). Kyseessä on omaisen arvio potilaan tarpeista.

Tehtävänannossa opiskelijoita ei ohjeistettu millään tavalla. Heitä pyydettiin vain pohtimaan tilannetta. Heitä ei esimerkiksi ohjattu pohtimaan tilannetta potilaan kohtaamisen ja lääkäri-potilas -suhteen kannalta, tai potilaan tai tämän omaisen tilanteeseen samastumisen kannalta. Tarkoituksena oli, että opiskelijat pohdiskelevat tehtävässä mahdollisimman vapaasti tilannekuvauksen synnyttämien reaktioiden pohjalta. Tällaisella tehtävänannolla toivottiin vältettävän sosiaalisesti suotava vastaaminen (ks. esim. 42-44). Opiskelijoiden ei haluttu sepittävän "oikeaoppisia" vastauksia. Se, miten he olisivat vastaavassa tilanteessa käyttäytyneet, saattaa tietysti poiketa heidän kirjallisista vastauksistaan. Käyttäytymisen tutkiminen edellyttäisi toista menetelmää, tavallisesti havainnointia. Toisaalta havainnoijan läsnäolo tilanteessa voi houkuttaa havainnoitavaa sopeuttamaan käyttäytymistään sosiaalisesti suotavaan suuntaan, esiintymään edukseen. Tehtävän tavoitteena ei ollutkaan käyttäytymisen tutkiminen, vaan käyttäytymisen taustalla vaikuttavien ajatusten ja järkeilyjen näkyväksi tekeminen ja analysoiminen. Toinen menetelmään liittyvä ongelma on opiskelijoiden paneutuminen tehtävään: kuinka vakavasti he suhtautuvat ja paneutuvat tehtävään ja kuinka tunnollisesti he vastaavat. Kirjoittaminen vaatii aina ponnisteluja ja eri ihmisiltä se sujuu vaihtelevalla vaivalla. Mutta riippumatta esimerkiksi vastauksen pituudesta, todennäköisesti vastaajat kuitenkin kiinnittävät vastauksissaan huomion omasta mielestään tärkeimpiin asioihin, mikä on tehtävän varsinainen tarkoituskin: miten lääkäriopiskelija hahmottaa vastaanottotilanteen, mihin hän kiinnittää siinä huomion, mitkä ovat tilanteen olennaiset elementit ja miten hän "järkeilee" niillä toimiessaan tilanteessa lääkärin roolissa?

Taulukko 1. Vastaajamäärät ja vastausprosentit.

\begin{tabular}{lccc}
\hline $\mathrm{N}=137$ & $\begin{array}{c}\text { Vuosi 2006 } \\
\text { koulutuksen } \\
\text { alussa }\end{array}$ & $\begin{array}{c}\text { Vuosi 2009 } \\
\text { koulutuksen } \\
\text { puolessa välissä }\end{array}$ & $\begin{array}{c}\text { Vuosi 2012 } \\
\text { koulutuksen } \\
\text { lopussa }\end{array}$ \\
\hline Tutkittavia & 98 & 83 & 57 \\
Tyhjiä & 3 & 2 & 6 \\
Vastanneita (n) & 95 & 81 & 51 \\
Vastausprosentti (\%) & $69 \%$ & $59 \%$ & $37 \%$ \\
\hline
\end{tabular}


Valitsimme aineistosta analysoitavaksi Turun lääketieteellisen tiedekunnan peruskoulutuksen lääkäriopiskelijoiden vastaukset vuosilta 2006, 2009 ja 2012, jolloin kyselylomakkeessa oli sama potilastapaus, ja vastaukset ovat keskenään vertailukelpoisia. Tarkastelukohdat sijoittuvat koulutuksen alkuun, puoleen väliin ja loppuun. Aineisto koostuu kaiken kaikkiaan 227 vastauslomakkeesta. Koulutuksen alussa vastaamisaktiivisuus oli suurinta (ks. taulukko 1). Loppua kohti vastausprosentti pienenee, mikä on paneelitutkimuksille tyypillistä. Vastauksia on kuitenkin kaikkina tarkasteluajankohtina riittävästi tutkimustarpeisiin. Koulutuksen alussa annetut vastaukset ovat pisimpiä. (Taulukko 2) Alkupuo- len vastaukset ovat esseenomaisia. Koulutuksen lopussa annetusta vastaustilasta on käytetty vain noin puolet. Kuudennen vuoden vastaukset ovat luettelonomaisia, ja aiempaa useammin ne esitetään ranskalaisten viivojen muodossa. Tuolloin lääkäriopiskelijat vastasivat samaan kyselylomakkeeseen jo kuudetta kertaa. Ehkä vastausväsymyskin jo vaikutti vastausten pituuteen ja sisältöön. Koulutuksen puolessa välissä annetut vastaukset vaihtelevat pituudeltaan eniten. Koulutuksen kaikissa vaiheissa potilastapausta oli pohdittu monesta eri näkökulmasta. Vastauksissaan lääkäriopiskelijat esittelivät eri vaihtoehtoja ja pohtivat niiden mukaisesti erilaisia toimintatapoja annetussa tilanteessa.

\footnotetext{
Opiskelijan vastaus opintojen alussa (2006):

"Potilas on lähetettävä tutkimuksiin, jotta voidaan aloittaa heti oikeanlainen hoito. Näin muistamattomuuden etenemistä kyetään hidastamaan mahdollisimman tehokkaasti. Yksin asuvalle vanhukselle pitää myös järjestää päivittäisiä virikkeitä ja huolehtia, että hänelle käy joku pitämässä säännöllisesti seuraa (esim. kotihoitaja). Vastaanotolla haastattelisin sekä tytärtä että potilasta ja koettaisin sitä kautta saada selville minkäasteisesta muistamattomuudesta on kyse. Usein on nimittäin niin, että dementian uhkaama vanhus vaikuttaa aluksi täysin terveeltä mutta mitä pidemmälle keskustelu etenee, sitä varmemmaksi käy että jotain on vialla, sillä pubeissa voi esiintyä ristiriitaisunksia, samojen asioiden toistamista yms. Tässä tapauksessa ensisijaisen tärkeää on siis aluksi selvittää mistä on kyse ja heti sen jälkeen rybtyä tarvittaviin hoitotoimenpiteisiin.” (111/T06)

Opiskelijan vastaus opintojen puolivälissä (2009):

"Ensin keskustelisin sekä äidin että tyttären kanssa siitä, millaisia oireet tarkemmin ovat, millaisissa tilanteissa ne tulevat, häiritsevätkö arkipäivää jne. Tekisin myös perustason muistikartoituksen, neurologisia testejä ym. Jos näiden perusteella on syytä epäillä aivoperäsitä sairautta, toki lähettäisin äidin sairaalaan tutkimuksiin. Potilaalla on kuitenkin oikeus kunnolliseen hoitoon ja ainakin kerran on hyvä tehdä perusteelliset tutkimukset sekä potilaan että omaistenkin mielenrauhan vuoksi. Toki pitää huomioida, onko potilaalla tarpeeksi virikkeitä elintmpäristössään ja mahdollisesti lisätä niitä ja parantaa potilaan asuinoloja, jos se on tarpeen.” (111/T09)

Saman opiskelijan vastaus opintojen lopussa (2012):

”Ensin pitää tehdä perusmuistitutkimukset tk:ssa ja sulkea pois ulkoiset syyt: alkoholi, yksinäisyys, liiallinen lääkitys jne. Vaikka lähete esh:oon sitten olisikin aiheen, syytä myös selvittää miten potilas pärjää kotona - asuu yksin, syökö? Miten siivousasiat, psyykkinen tilanne, yksinäisyys, lääkkeiden otto. Myös vakavat somaattiset syyt mietittävä: aivotapahtumia, traumaa (pään) ja näiden perusteella tehtävä huolelliset tutkimukset. Tietysti myös pidettävä mielessä, onko omaiset (tytär) täysin vilpittömästi tuomassa äitiä vo:lle joskus (onneksi harvoin) voi taustalla olla vanhan äidin rabojen himo tms. Ei mikään helppo tapaus siis! (111/ T12)
}

Taulukko 2. Esimerkki lääkäriopiskelijan vastauksista koulutuksen alussa, puolivälissä ja lopussa.

Tutkimusaineistoa analysoitiin induktiivisen sisällönanalyysin ja sisällönerittelyn keinoin. Ensin aineisto luettiin useaan kertaan. Sisältöön perehtymisen jälkeen merkittiin ylös alkuperäisilmauksia, jotka nousivat aineistosta toistuvasti esiin. Analyysiyksikkönä on ilmaus, ja jokaista ilmausta vastaa yksi lääkäriopiskelija. Yhden lääkäriopiskelijan kirjoittama vastaus sisältää siis monta eri analyysiyksikköä. Tämän jälkeen yhdisteltiin yksityiskohtaisemmin alkuperäisilmaukset pelkistettyjen otsikoiden alle (ks. taulukko 3). Pelkistyksistä syntyi yhdeksän alaluokkaa: empatia, omaiseen suhtautuminen, kontekstia täydentävät oletukset, potilaaseen suhtautuminen, uskomukset, päätöksenteko, toimenpiteet, kokonaisuuden tarkastelu ja moniammatillinen yhteistyö. Tämän jälkeen määriteltiin tarkoin, mitä kukin alaluokka merkitsee ja mitä se ei mer- 
Taulukko 3. Sisällönanalyysi lääkäri-potilas suhteen hallintaan vaikuttavista tekijöistä.

\begin{tabular}{|c|c|c|c|}
\hline Alkuperäisilmaus & Pelkistys & Alaluokka & Pääluokka \\
\hline $\begin{array}{l}\text { "Ketään ei voi pakottaa tutkimuksiin } \\
\text { eli läkärin tulisi selvittää tilannetta } \\
\text { vanhan naispotilaan kannalta." } \\
\text { (064/T06) } \\
\text { ”Vastaanotolla pitäisi keskittyä äitiin } \\
\text { eikä tyttären, tutkia potilas hyvin ja } \\
\text { yrittää saada häneltä itseltään käsitys } \\
\text { tilanteesta." (141/T09) } \\
\text { ”Mitä mieltä potilas itse?” (081/T12) }\end{array}$ & $\begin{array}{l}\text { - potilaan oman mielipiteen } \\
\text { selvittäminen } \\
\text { - esitietojen kerääminen } \\
\text { - potilaan itsemääräämis- } \\
\text { oikeuden ja oman tahdon } \\
\text { kunnioitus }\end{array}$ & $\begin{array}{l}\text { Potilaaseen } \\
\text { suhtautuminen }\end{array}$ & \multirow{4}{*}{$\begin{array}{l}\text { Lääkäri- } \\
\text { potilas } \\
\text { suhteen } \\
\text { hallintaan } \\
\text { vaikuttavat } \\
\text { tekijät }\end{array}$} \\
\hline $\begin{array}{l}\text { "Naispotilas asuu luultavasti leskenä } \\
\text { omassa kodissaan.” (121/T06) } \\
\text { "Tytär pelkää äitinsä sairastavan } \\
\text { jotain vakavaa - pelkää kenties } \\
\text { olevan jotain perinnöllistä tautia" } \\
\text { (058/T06) } \\
\text { ”Olen viime aikoina joutunut } \\
\text { seuraamaan juuri samanlaista } \\
\text { tilannetta" (070/T06) } \\
\text { "ei vaikuta laisinkaan siltä, } \\
\text { etteikö potilas pystyisi itse omaa } \\
\text { terveydentilaansa arvioimaan." } \\
\text { (125/T06) }\end{array}$ & $\begin{array}{l}\text { - jotain mitä potilastapaus ei } \\
\text { kerro } \\
\text { - kuvittelee ja päättelee } \\
\text { puuttuvat aukot } \\
\text { - tietämykseen ja } \\
\text { kokemuksiin perustuvia } \\
\text { oletuksia }\end{array}$ & $\begin{array}{l}\text { Kontekstia } \\
\text { täydentävät oletukset }\end{array}$ & \\
\hline $\begin{array}{l}\text { ”Hyvä juttu jotta potilaalla on } \\
\text { välittäviä omaisia." (023/T09) } \\
\text { "Itse suhtaudun tyttären huoleen } \\
\text { ymmärtävästi - "(033/T09) } \\
\text { "-llääkärin tulee olla kyseisessä } \\
\text { tilanteessa äärimmäisen } \\
\text { ymmärtäväinen - "(036/T06) } \\
\text { ”Tulee sääli tyttöä, joka tuntuu } \\
\text { olevan huolissaan äidistä." } \\
\text { (149/T06) } \\
\text { "Yritän miettiä tilannetta potilaan } \\
\text { kannalta." (005/T06) }\end{array}$ & $\begin{array}{l}\text { - kyky asettua potilaan/ } \\
\text { omaisen asemaan } \\
\text { - kyky yrittää ymmärtää } \\
\text { potilaan/omaisen tunteita } \\
\text { - kyky myötäelää }\end{array}$ & Empatia & \\
\hline $\begin{array}{l}\text { "Haluaisin haastatella 78-vuotiasta } \\
\text { myös ilman tyttären läsnäoloa" } \\
\text { (009/T09) } \\
\text { "oireet voivat olla tyttären } \\
\text { kuvittelemia" (134/T06) } \\
\text { "taustalla voi olla vanhan äidin } \\
\text { rahojen himo tms."(111/T12) } \\
\text { "On hyvä, että tytär on tiedostanut } \\
\text { tilanteen -" (036/T06) } \\
\text { "Lääkärin on kuunneltava } \\
\text { lähiomaista, sillä lähiomainen } \\
\text { huomaa kyseiset oireet helpommin } \\
\text { kuin lääkäri” (043/T06) } \\
\text { "Tyttären tuki on varmasti } \\
\text { vanhukselle tärkeä, joten myös } \\
\text { hänet on huomioitava ristiriitojen } \\
\text { välttämiseksi." (064/T06) }\end{array}$ & $\begin{array}{l}\text { - } \text { omainen on } \\
\text { asiaankuulumaton } \\
\text { - omaiseen kohdistuvat } \\
\text { epäilykset } \\
\text { - } \text { omaisen motiivit } \\
\text { - omaisen huoli } \\
\text { - omainen vastuunkantajana } \\
\text { - esitietojen kerääminen } \\
\text { - } \text { omaisen arvostaminen }\end{array}$ & $\begin{array}{l}\text { Omaiseen } \\
\text { suhtautuminen }\end{array}$ & \\
\hline
\end{tabular}




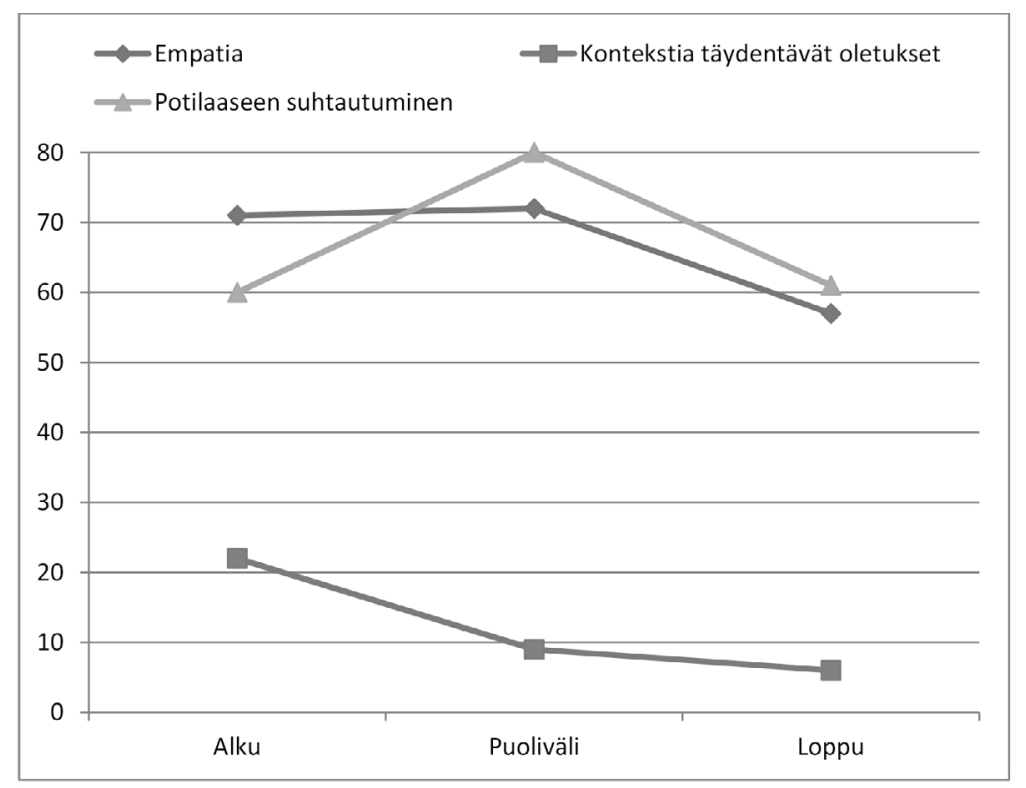

Kuvio 1. Potilaaseen suhtautuminen, kontekstia täydentävät oletukset ja empatia lääkärikoulutuksen alussa, puolivälissä ja lopussa: esiintymien osuudet lääkäriopiskelijoiden kirjoituksissa (\%).

kitse. Alaluokista sekä niitä määrittävistä käsitteistä tehtiin matriisi. Seuraavaksi tarkasteltiin aineisto läpi tehden sovittuja merkintöjä matriisin avulla ja etsien edellä kuvattujen alaluokkiin luettavat esiintymät. Tarkastelussa keskityttiin lääkäriopiskelijoiden välittämiin merkityksiin, ei ainoastaan sanojen laskemiseen. Alaluokat ryhmittyivät kahteen pääluokkaan: (1) lääkäripotilas suhteen hallintaan vaikuttaviin tekijöihin ja (2) ongelmanratkaisun hallintaan vaikuttaviin tekijöihin. Pitkittäistarkastelussa nämä yhdessä kuvaavat lääkäriopiskelijan ammatillista kasvua $(45,46)$. Tässä artikkelissa keskitymme lääkäripotilas suhteen hallintaan ja sen muutokseen koulutuksen aikana. Aineistosta muodostui kyseiselle pääluokalle neljä alaluokkaa: (i) potilaaseen suhtautuminen, (ii) kontekstia täydentävät oletukset, (iii) empatia ja (iv) omaiseen suhtautuminen (taulukko 2).

\section{TULOKSET}

Tulokset esitetään seuraavassa prosenttiosuuksia kuvaavina kuvioina, joista nähdään, kuinka suuressa osuudessa vastauksia alaluokkiin lukeutuvat ilmaukset esiintyvät. Yleistettynä aineistosta saadut tulokset kuvaavat, miten lääkäri-potilas -suhteen neljä osa-aluetta (potilaan huomioiminen, kontekstia täydentävät oletukset, empatia ja omaisen huomioiminen) ilmenevät ja mahdollisesti muuttuvat lääkärikoulutuksen aikana.

Aineiston analyysi onnistuu mielestämme osoittamaan kahdenlaisia eroja. Ensinnäkin, lääkäriopiskelijoiden kirjoituksissa näkyvät painotuserot: tietyt aineistosta muodostuneet osaalueet esiintyvät kirjoituksissa useammin kuin toiset. Toiseksi voimme sanoa jotain eri vuosien "mittauksissa" saatujen tulosten muutoksesta. Muutoksen tulkinnassa on syytä noudattaa varovaisuutta, koska vastaajajoukon koko vaihtelee: mitä pidemmälle koulutus etenee, sitä pienemmäksi vastaajajoukko käy (ensimmäisenä vuonna vastaajia 95, toisena 81 ja kolmantena 51; ks. edellä taulukko 1). Kuten itse analyysi, myös tulosten esitystapa hyödyntää sekä määrällistä että laadullista tutkimusotetta.

\section{POTILAASEEN SUHTAUTUMINEN}

Potilas nousee tutkimusaineistossa odotetusti keskeiseen rooliin. Potilaaseen suhtautumisen alaluokka koostuu lääkäriopiskelijan ajatuksista ja pohdinnoista potilasta kohtaan. Aineistosta nousee erilaisia näkökulmia sekä tapoja suhtautua potilaaseen. Koulutuksen joka vaiheessa potilas huomioidaan vastauksissa hyvin (kuvio 1). 
Eniten potilaaseen kohdistuneita ilmauksia aineistosta löytyy koulutuksen puolivälissä (80 prosentilla vastaajista) kun taas koulutuksen alussa ja lopussa lähes yhtä paljon (noin 60 prosentilla vastaajista). Koko koulutuksen aikana esiintynyt suhtautuminen potilasta kohtaan on luonteeltaan positiivista. Yleisin tapa koulutuksen joka vaiheessa on huomioida potilaan oma tahto ja näkemys tilanteesta. Annetussa potilastapauksessa omaisen ääni on itse potilasta kuuluvammin esillä. Tämän seurauksena vastauksissa yleisemmin nousee esille potilaan itsensä kuulemisen tärkeys. Koulutuksen kaikissa vaiheissa vastauksista käy ilmi, että vastaanottotilanteessa lääkäri keskittyy nimenomaan potilaaseen eikä omaiseen.

"Mielestäni olisi tärkeää saada tietoon vanhuksen oma mielipide -" (015/T06)

"Lääkärin täytyy jutella potilaan kanssa -" (025/T09)

"Haluaisin tietää pot. itsensä kuvauksen tilanteesta" (009/T12)

Koulutuksen alussa potilaaseen suhtautuminen on hienovaraista, ja siinä näkyy voimakkaana potilaan kunnioitus. Lääkäriopiskelijat pohtivat omaa käyttäytymistään vastaanottotilanteessa, mielekästä potilaan kohtaamista sekä mahdollisia vuorovaikutuksellisia haasteita.

”On kysyttävä naispotilaan mielipidettä hellävaroin hermostuttamatta tytärtä (haasteellinen juttu).” (073/T06)

"Myös äidin on myös itse kerrottava oireitaan ja antaa hänellekin suunvuoro." (025/T06)

”Hyvänä lääkrinä minun olisi kyettävä selvittämään todellinen syy tyttären ja äidin vastaanotolle tuloon toimimalla hienovaraisesti kumpaakin kohtaan." (027/T06)

”Terveysaseman lääkärin tulee kyseisessä tilanteessa olla äärimmäisen ymmärtäväinen ja jaksaa selittää mahdollisia vaibtoehtoja ja boitoja niin perusteellisesti ja kärsivällisesti että iäkäs naispotilas itsekin ymmärtää tilanteen." (036/T06)

"On oltava myös tietysti kunnioittava ja potilasläheinen.” (038/T06)
Koulutuksen lopussa potilaan huomioimista on määrällisesti yhtä paljon, mutta laadultaan se on erilaista. Koulutuksen lopussa potilaan huomioimista on pohdittu paljon vähäsanaisemmin. Tuolloin näkökulmat viittaavat jo selvästi omakohtaisempiin kokemuksiin, joita mahdollisesti työharjoitteluiden yhteydessä on potilaiden kanssa koettu. Koulutuksen lopussa vastauksissa korostuu pyrkimys päästä potilaan kanssa yhteisymmärrykseen.

”-mistä varmasti päästään potilaan ja tyttären kanssa ybteisymmärrykseen.” (003/T12)

Kun koulutuksen alussa ja puolivälissä potilaan oman tahdon ja itsemääräämisoikeuden toteutumista pidetään tärkeänä, osataan koulutuksen lopussa sen toteutumista jo kuvailla konkreettisesti. Koulutuksen alussa ja puolivälissä potilaalta kysytään, keskustellaan, jutellaan ja selvitetään, kun taas koulutuksen lopussa otetaan anamneesia.

\section{"lääküin tulee osata kysyä tältä tilannetta oikealla tavalla kartoittavia kysymyksiä." (002/T06)}

"täytyy tarkentaa anamneesia - " (108/T12)

\section{KONTEKSTIA TÄYDENTÄVÄT OLETUKSET}

Annetussa potilastapauksessa informaatio on verraten niukkaa. Opiskelijat joutuvat pohtimaan potilaan taustoja, elämäntilannetta, saattajana olevan omaisen roolia ja muuta tilanteeseen liittyvää. He joutuvat tekemään oletuksia. Kontekstia täydentävät oletukset ovat lääkäriopiskelijan tietämykseen ja kokemukseen perustuvia, todennäköisiä arvioita potilastapauksesta. Tehtävänä oleva potilastapaus sinällään ei niitä kerro. Tähän luokkaan kuuluvat ilmaukset, joissa on täsmennetty potilastapauksessa annettua informaatiota oman ajattelun keinoin. Lääkäriopiskelija on kaivannut potilastapauksen kontekstiin liittyvää lisäinformaatiota ja tarkennusta, jonka hän itse tuottaa päättelemällä ja kuvittelemalla aukkokohdat. Kontekstia täydentävät oletukset ovat tietynlaista spekulaatiota, jossa lääkäriopiskelija hyödyntää käytössä olevan informaation lisäksi omaa kokemustaan ja asiantuntemustaan rakentaen niiden avulla informatiivisemman kuvan tapauksesta. Tällainen spekulointi voi johtaa myös vähättelevään ja piittaamattomaan suhtau- 
tumiseen annettua informaatiota kohtaan. Silloin voidaan puhua myös ennakkoluuloisesta suhtautumisesta potilaaseen (ja/tai omaiseen).

Koulutuksen alussa potilastapaus panee opiskelijat tekemään täydentäviä oletuksia selvästi voimakkaimmin (kuvio 1). Usealla lääkäriopiskelijalla tällainen tilanteeseen eläytymisen "tekstittäminen" vie paljon vastaukseen annetusta tilasta. Koulutuksen alussa täydentävien oletusten tekeminen on luonteeltaan tunnepitoista - ja enimmäkseen positiivista.

"Vanhus on todennäköisesti asunut yksin puolisonsa kuolemasta lähtien, ja ollut kenties masentunut ja yksinäinen. Virikkeetön elämä on mahdollisesti kasvavassa määrin tehnyt hänestä "mökkihöperön", eikä bänellä ole riittänyt halua huolehtia itsestään. Hän on mitä luultavimmin alkanut jättää aterioita syömättä ja nukkua iltapäivään saakka. Sekavuus ja huimaus saattavat johtua häiriöistä lääkkeiden syömisestä.” (003/T06)

Lääkäriopiskelija siis tarvitsee lisäinformaatiota potilastapauksen käsittelyyn, ja koska sitä ei ole ollut tarjolla, hän kuvittelee sen itse. Hän taustoittaa tapausta. Koulutuksen alussa on myös käsitelty omakohtaisia kokemuksia vastaavista tilanteista, jotka on nostettu pohdintaan. Omat kokemukset ovat eräänlainen tulkintaresurssi, joka auttaa ymmärtämään annettua tapausta.

"Olen viime aikoina joutunut seuraamaan juuri samanlaista tilannetta. - Isoäitini oli tämän potilaan asemassa -” (070/T06)

Vastaavaa omakohtaisiin kokemuksiin liittyvää pohdintaa ei enää esiinny koulutuksen myöhemmissä vaiheissa. Pääasiassa kaikissa tilanteeseen eläytymistä sävyttäneissä pohdinnoissa, omaa kuviteltua lisäinformaatiota on tavalla tai toisella käytetty rakennusaineena. Koulutuksen puolivälissä $(9 \%)$ ja lopussa $(6 \%)$ kontekstia täydentäviä oletuksia esiintyy kaiken kaikkiaan vain vähän. Tuolloin kaikki täydentävät oletukset liittyvät sisällöltään omaisen motiiveihin: lääkäriopiskelija epäilee omaisen motiiveja, jotka hän kuitenkin on tuottanut itse. Näitä "epäilyttäviä motiiveja” ei ole mainittu tehtävänä olevassa potilastapauksessa. Mikään tehtävässä ei vihjaa mihinkään epäilyttävään.
”Tytär yrittää kenties poistaa murhetta aibeuttavan äidin huolenaiheistaan ja laittaa laitosboitoon.” (105/T09)

Omaisen uskotaan liioittelevan, holhoavan, kokevan syyllisyyttä, kärsivän työstressistä, olevan liian kiireinen huolehtimaan potilaasta, tai hänellä arvellaan olevan huonoja kokemuksia terveyskeskuksen toiminnasta. Koulutuksen lopussa esiintyneet kontekstia täydentävät oletukset ovat sävyltään eniten negatiivisesti tai kyynisesti sävyttyneitä.

"Tytär haluaa mahdollisesti äitinsä hoitokotiin ja haluaisi tutkimuksilla Kelan tukea hoitokodissa asumiselle." (105/T12)

”Ärsyttää, että potilaat/omaiset tulee ilmoittamaan ja vaatimaan asioita, eivätkä anna mahdollisuutta tk-lääkärille antaa muita vaibtoehtoja ratkaisuiksi.” (012/T12)

On syytä panna merkille, että täydentäviä oletuksia esiintyy koulutuksen puolessa välissä ja lopussa vain yksittäisinä tapauksina, ja tällöin niissä on havaittavissa myös yksilöllisiä eroja. Kuten edellisistä lainauksista huomaa, esiintyneet ilmaukset ovat keskittyneet tietyille lääkäriopiskelijoille.

\section{EMPATIA}

Empatia on kykyä asettua potilaan tai omaisen asemaan sekä kykyä ymmärtää heidän tunteitaan, ajatuksiaan tai elämäntilannettaan. Koulutuksen alussa ja keskivaiheilla lääkäriopiskelija myötäelää tilanteessa tai samastuu hetkellisesti toisen ihmisen osaan todennäköisemmin kuin koulutuksen lopussa. Koulutuksen alussa ja puolivälissä annetuissa vastauksissa ilmenee empatiaa verraten runsaasti (kuvio 1).

"Yritän miettiä tilannetta potilaan kannalta." (005/T06)

"-lääkärin tulee olla kyseisessä tilanteessa äärimmäisen ymmärtäväinen.” (036/T06)

”Tulee sääli tyttöä, joka tuntuu olevan huolissaan äidistä.” (149/T06)

Empaattisuus välittyy vastauksissa monipuolisesti. Niissä kuvastuu, kuinka lääkäriopiskelijat asettuvat sekä potilaan että tyttären asemaan ja pohtivat tilannetta heidän kannaltaan. Verrattu- 
na koulutuksen seuraaviin vaiheisiin, koulutuksen alussa empatiaa on käsitelty kokonaisvaltaisemmin sekä syvällisemmin. Koulutuksen alussa lääkäriopiskelijat samastuvat hetkellisesti toisen ihmisen osaan ja miettivät muun muassa sitä, miksi vanhukset yleensä haluavat pysyä kotonaan. Näin ollen he tarkastelevat potilastapausta empaattisesti laajemmassa kontekstissa. Koulutuksen puolivälissä empaattisuutta ilmenee määrällisesti saman verran kuin koulutuksen alussa, mutta se on huomattavasti yksipuolisempaa eikä empaattisiin pohdintoihin ole käytetty yhtä paljon vastaustilaa.

Koulutuksen lopussa on kiinnitetty vähiten huomiota empaattisuuteen. Empatia välittyy teksteistä, mutta se on huomattavasti yksipuolisempaa. Pääasiassa maininnat koskevat omaisen huolta potilaasta. Vastauksissa kuvastuu ymmärrys siitä, että omainen on huolissaan vanhasta äidistään. Koulutuksen lopussa empatia siis kohdistuu pääasiassa omaiseen. Itse potilaaseen kohdistuvia empaattisia viestejä havaittavissa on vain vähän. Kyynisyyttä esiintyy eniten koulutuksen lopussa.

”Ärsyttävää, että ihmiset tulevat tk-puolelle "shoppailemaan" ja suurin osa työstä on "tyttärien” hoitamista.” (058/T12)

Empaattista ajattelua rajaa myös keskittyminen erilaisiin käytännön seikkoihin kuten resurssipulaan, jonka seurauksena välittyy kyynisiä piirtei- tä. Aineistosta voi päätellä, että toiset vastaukset ovat empaattisempia kuin toiset. Osa vastauksista erottuu selvästi empaattisina pohdintoina, kun taas toisista empaattisuutta on vaikeampi havaita. Rajan vetäminen empaattisten ja epäempaattisten pohdintojen välille ei ole tässä tutkimusaineistossa helppoa.

\section{OMAISEEN SUHTAUTUMINEN}

Omaiseen suhtautumisessa esille nousivat omaisen asiaankuulumattomuus vastaanottotilanteessa, omaiseen kohdistuvat epäilyt, omaisen motiivit ja omaisen tuntema huoli. Näiden lisäksi vastauksissa kiinnittyy huomio omaiseen vastuunkantajana ja lääkäriopiskelijan omaista kohtaan ilmaisemaan arvostukseen. Nämä kuusi tapaa suhtautua omaiseen jakautuvat ilmaisutavoiltaan positiivisiin ja negatiivisiin. Kun omainen koetaan tilanteessa asiaankuulumattomaksi, häneen kohdistuu erilaisia epäilyjä tai omaisen motiiveja pohditaan, luokittelimme nämä ilmaisut luonteeltaan negatiivisiksi. Vastaavasti omaisen huoli, omaisen rooli vastuunkantajana sekä omaisen arvostus ovat selvästi positiivisesti latautuneita ilmaisuja. Neutraaleiksi luokittelimme tapaukset, joissa on sekä positiivisia että negatiivisia ilmauksia.

Koulutuksen joka vaiheessa selvästi yli puolet lääkäriopiskelijoista ilmaisee ajatuksiaan omaiseen kohdistuen: alussa $67 \%$, koulutuksen puolessa välissä $73 \%$ ja koulutuksen lopussa $57 \%$ (kuvio 2).

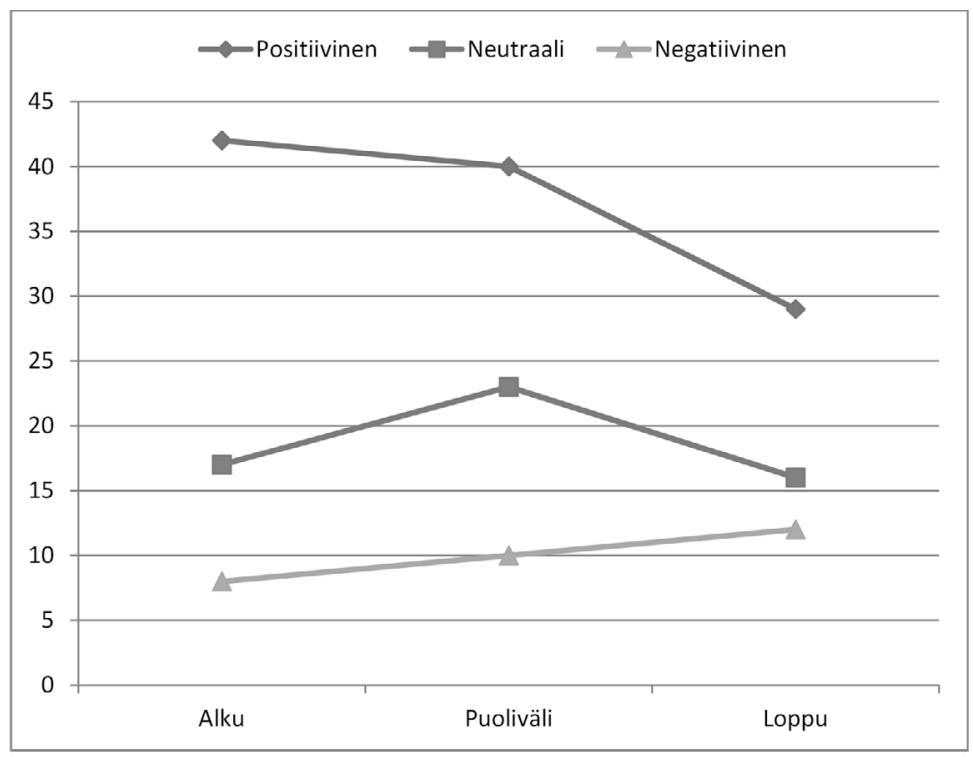

Kuvio 2. Omaiseen suhtautuminen lääkärikoulutuksen alussa, puolivälissä ja lopussa: esiintymien osuudet lääkäriopiskelijoiden kirjoituksissa (\%) 
Koulutuksen joka vaiheessa on positiivisesti latautuneita ilmauksia enemmän kuin negatiivisia tai neutraaleja. Koulutuksen alussa suhtautuminen omaiseen on positiivisinta ja koulutuksen lopussa negatiivisinta. Asia voidaan tulkita myös siten, että koulutuksen lopussa positiivisia ilmauksia on vähiten. Koulutuksen lopussa omaista kohtaan välitetään kunnioitusta kuitenkin yhtä paljon kuin koulutuksen muissakin vaiheissa. Eniten tilaa näihin ilmauksiin on käytetty koulutuksen alussa, mutta monipuolisinta sekä useimpia eriäviä ilmauksia esiintyy koulutuksen puolessa välissä, jolloin suhtautuminen omaiseen on neutraaleinta.

Koko koulutuksen aikana omaisen rooli nähdään vastuunkantajana. Näitä ilmaisuja esiintyy kaiken kaikkiaan koko aineistossa eniten. Ilmaisut, joissa omaista käytetään apuna esitietojen kokoamisessa ja tilanteen kartoittamisessa, ovat hyvin tyypillisiä. Omaisella koetaan olevan sellaista tärkeää informaatiota, jota potilas itse ei mahdollisesti osaa tai pysty tuomaan vuorovaikutukseen.

”Tytär saattaa tietää paljon äidin elämästä ja on hyödyllinen tiedonlähde - ” (117/T09)

Erityisesti koulutuksen lopussa omaisen vastuunkantaminen näkyy pohdinnoissa, joissa omaiselle annetaan vastuuta myös jatkotoimenpiteiden huolehtimisessa.

"Tämän selittäisin potilaalle ja tyttärelle. - läakityksen aloittaminen avohoidossa, jos vaikka tytär voisi auttaa.” (076/T12)

"Itse subtaudun tyttären huoleen ymmärtäväisesti ja pidän myös hänet ajan tasalla potilaan tutkimuksista ja jatkotoimenpiteistä.” (033/ T09)

Toiseksi eniten aineistosta löytyy ilmauksia omaisen huoleen liittyen. Koulutuksen alussa käsitellään eniten omaisen kantamaa huolta potilaasta.

"78-vuotiaalla on alkanut ilmaantua ikääntymisen merkkejä, ja tytär on tästä syystäkin buolissaan.” (034/T06)
"Koska tytär on kuitenkin tuonut äitinsä vastaanotolle ja on huolissaan, niin asia pitää ottaa vakavasti ja antaa lähete keskussairaalaan tutkimuksia varten. Mikäli äiti on kuitenkin sitä mieltä, että hän ei ole muistamaton ja vastustaa tutkimuksia, pitäisi löytää kompromissiratkaisu. Sen edellytyksenä on kuitenkin äidin ja tyttären mielipiteiden kuuntelu. Yleensä varmaankin tytär on oikeassa." (038) T06)

Koulutuksen alussa vastauksista välittyy samalla hyvin kunnioittava ja arvostava sävy omaista kohtaan, johon on voitu käyttää paljonkin annetusta tilasta. Negatiivisista ilmauksista koko aineistossa on eniten omaiseen kohdistuneita epäilyjä.

”jos äiti asuu yksin, miten tytär voi olla tietoinen niin tarkkaan hänen terveydentilastaan?" (127/T06)

"voi taustalla olla vanhan äidin rahojen himo tms."(111/T12)

Omaisen motiivien epäilyä esiintyy vastauksissa koulutuksen joka vaiheessa, mutta koulutuksen lopussa ne korostuvat selvästi. Tuolloin myös omaisen motiivien epäileminen on hiukan yleisempää kuin opintojen aiemmissa vaiheissa. Vastaavasti koulutuksen lopussa omaisen asiaankuulumattomuutta tilanteessa pohditaan vähiten.

\section{YHTEENVETO TULOKSISTA}

Olemme tässä artikkelissa tutkineet lääkäriopiskelijoiden tapaa tulkita samaa potilastapausta sekä lääkäri-potilas suhteen ilmauksissa havaittavia muutoksia koulutuksen eri vaiheissa. Aineistona käytimme kuuden vuoden aikavälillä kyselylomakkeella opiskelijoilta kerättyjä vastauksia tehtävään, joka kuvaa lääkärin vastaanotolle omaisen kanssa tulevaa iäkästä potilasta. Opiskelijoiden tehtävänä oli kuvata, miten he reagoivat ja toimivat vastaanottotilanteessa. Analysoimme 227 kyselylomakkeen aineistosta, miten lääkäripotilas -suhde ilmenee opiskelijoiden kirjoittamissa kuvauksissa opintojen eri vaiheissa (alussa, puolivälissä ja lopussa). Tehtävänannossa ei kerrottu, että vastauksia tullaan tarkastelemaan lääkäri-potilas -suhteen näkökulmasta. 
Vuorovaikutukseen liittyvät ilmaukset luokittuvat neljään kategoriaan, jotka nimesimme seuraavasti: (i) potilaaseen suhtautuminen, (ii) kontekstia täydentävät oletukset, (iii) empatia ja (iv) omaiseen suhtautuminen. Näihin neljään lääkäri-potilas -suhteen kehitykseen vaikuttavien tekijöiden alaluokkaan kuuluvat ilmaukset esiintyvät kirjoituksissa eri painoarvolla koulutuksen eri vaiheissa. Ilmausten esiintymisessä on havaittavissa tiettyjä systemaattisia muutoksia.

Koulutuksen alussa lääkäriopiskelijat kiinnittivät eniten huomiota vuorovaikutukseen. Koulutuksen alussa lääkäriopiskelijoiden ilmaukset sisältävät paljon empatiaa ja kontekstia täydentäviä oletuksia. Lääkäriopiskelija asettuu potilaan asemaan ja eläytyy tämän tuntemuksiin. Opiskelija täydentää potilastapauksesta annettua niukkaa informaatiota tekemällä runsaasti oletuksia potilaan elämäntilanteesta, saattajana olevasta omaisesta ja heidän suhteestaan sekä omaisen huolista.

Koulutuksen puolessa välissä suhtautuminen potilaaseen ja omaiseen on edelleen positiivinen, mutta negatiiviset ilmaisut ovat yleisempiä kuin koulutuksen alussa. Lääkäriopiskelijat huomioivat potilaan ja omaisen niin opintojen alussa, puolivälissä kuin lopussakin, mutta suhtautumistapa on koulutuksen eri vaiheissa laadultaan erilainen. Tulkitsemme muutoksen merkitsevän sitä, että koulutuksen kuluessa vuorovaikutustaidot ovat kehittyneet ja ammatillistuneet. Koulutuksen edetessä lääkäriopiskelijat eivät suhtaudu potilaaseen yhtä hienovaraisesti kuin koulutuksen alussa, mutta he pyrkivät pääsemään yhteisymmärrykseen potilaan kanssa. Tietynlainen konsensushakuisuus potilaan ongelman ratkaisemiksi lisääntyy koulutuksen edetessä.

Koulutuksen lopussa opiskelijat kokevat omaisen olennaisen tärkeäksi osallistujaksi vuorovaikutustilanteessa ja vastuunkantajaksi iäkkään potilaan asioissa. Mutta tuolloin lääkäriopiskelijat myös eniten epäilevät omaisen motiiveja. Samalla kun opiskelijat ovat tietoisia omaisen vastuullisesta asemasta potilastapauksessa, he eivät itsestään selvästi usko tämän ajavan vain potilaan etua. Koulutuksen lopussa opiskelijat osaavat parhaiten hyödyntää omaista potilaan sairautta, terveydentilaa ja elämäntilannetta koskevien tietojen kokoamisessa, ohjeistuksessa ja jatkohoidosta huolehtimisessa. Suh- tautuminen omaiseen on kuitenkin koulutuksen lopussa negatiivisempaa kuin aiemmin. Silloin opiskelijoiden vastauksissa esiintyy vähemmän empatiaa kuin koulutuksen varhaisemmissa vaiheissa. Niin ikään opiskelijat tekevät aiempaa vähemmän kontekstia täydentäviä oletuksia. Voidaan sanoa, että potilaan elämäntilanteen pohdinta ja "tunteilu” vähenevät koulutuksen edetessä. Mikäli tulos kuvastaa lääkärikoulutuksen tavoitteiden toteutumista, kysymys on ammatillisen varmuuden lisääntymisestä.

\section{POHDINTA}

Tutkimuksessa käytetyn menetelmän tuottamat tärkeimmät havainnot ovat lääkäriopiskelijoiden empatian väheneminen ja saattajana olevaan omaiseen suhtautumisen muuttuminen luonteeltaan epäilevämmäksi. Empatian väheneminen opintojen kuluessa on todennettu useissa tutkimuksissa (47-51), ja on mielenkiintoista huomata sen käyvän ilmi myös opiskelijoiden itsensä tuottamasta kirjallisesta aineistosta. Havainto omaiseen suhtautumisen muutoksesta on sikäli merkityksellinen, ettei sitä välttämättä edes havaita useimmissa tutkimuksissa. Tässäkin tutkimuksessa se nousee esiin vain käytetyn menetelmän ja siihen sisällytetyn potilastapauskuvauksen ansiosta. Omaiseen suhtautumisen muuttumisesta voidaan tehdä päätelmiä vain seuraamalla, miten saman opiskelijan tai opiskelijajoukon toiminta muuttuu tilanteessa, jossa vastaanotolle tulevalla potilaalla ylipäätään on omainen mukanaan saattajana. Kontekstia täydentävien oletusten näkyväksi tekeminen on niin ikään yksi tämän tutkimuksen ansioista. Tämänkaltaista järkeilyä ei voi havaita suoraan esimerkiksi vastaanottotilannetta observoimalla. Tehty analyysi muistuttaa myös siitä, että kontekstia täydentävät oletukset, paitsi auttavat lääkäriä täyttämään järkeilemällä tiedollisia aukkokohtia, voivat johtaa myös vääriin tulkintoihin potilaasta, tämän tilanteesta tai omaisesta, mikäli lääkäri ei myöhemmin varmista niiden todenperäisyyttä.

Vaikka tässä tutkimuksessa käytetyllä menetelmällä on puutteensa, sillä on myös etuja esimerkiksi havainnointiin, itsearviointiin tai potilaskyselyyn verrattuna. Havainnointi toteutetaan lähes poikkeuksetta niin, että havainnoija on mukana tilanteessa, mikä jo sinänsä tekee tilanteesta epänormaalin, ja useimmissa 
tapauksissa vaikuttaa havainnoitavien henkilöiden käyttäytymiseen $(10,15)$. Jos havainnoitava vastaanottotilanne saadaan säilytettyä sellaisena, että havainnointi ei pääse vaikuttamaan sen enempää lääkärikandidaatin kuin vastaanotolle tulevan potilaankaan käyttäytymiseen, saadaan toki luotettavia tuloksia. Tämän toteuttaminen ei kuitenkaan ole helppoa. Todennäköisesti havainnoijan läsnäolo vastaanottotilanteessa vaikuttaa siten, että lääkäriopiskelija pyrkii esiintymään tilanteessa - osin tietoisesti ja osin tiedostamattaan - mahdollisimman tunnollisesti eettisen koodiston mukaisesti koettaen antaa itsestään ammattimaisen kuvan. Havainnointi voidaan toteuttaa myös ikkunan takaa, jolloin havainnoija ei ole "häiritsemässä" itse vastaanottotilannetta. Mutta tietoisuuskin havainnoitavana olemisesta vaikuttaa käyttäytymiseen, eikä se näin ollen poista menetelmän ongelmaa. ${ }^{1}$

Havainnointi on monin tavoin hyvä menetelmä käyttäytymisen ja sen muutosten tutkimiseksi, mutta suuren tapausmäärän hankkiminen havainnoimalla on aikaa vievää, työlästä ja myös kallista. Mutta suurempi ongelma on se, ettei vastaanottotilannetta ole mahdollista vakioida sillä tavoin kuin tämän tutkimuksen kirjallisessa tehtävässä on tehty. Käyttämässämme tehtävässähän potilastapaus henkilöineen ja oireineen pysyy samanlaisena läpi koko tarkastelujakson. Asetelma on aina sama; vain lääkäriopiskelijan reagointi tapaukseen muuttuu - jos muuttuu. Yli kahdensadan vakioidun tarkastelutapauksen kerääminen havainnoimalla voisi olla jopa mahdotonta. On ymmärrettävää, että havainnointi toteutetaan yleensä pienemmässä joukossa, seuraamalla toimintaa vain muutamassa yhteisössä (vastaanotolla, sairaalassa, hoitopaikassa). Tarkoituksenamme onkin tutkimuksen seuraavassa vaiheessa havainnoida vuorovaikutustaitojen välittymistä opetustilanteessa hajautetussa lääkärikoulutuksessa. Etnografisella tutkimusotteella

\footnotetext{
${ }^{1}$ Havainnointiin peili-ikkunan takaa liittyy myös eettisiä ongelmia. Lääkärikokelaat varmaankin hyväksyisivät tällaisen "piilotetun" havainnoijan käyttämisen, mutta potilaalle tilanne voisi olla epämiellyttävämpikin kuin läsnä olevan havainnoijan käyttäminen. Potilaalla pitää tietenkin olla mahdollisuus kieltäytyä myös tällaisesta havainnointimenetelmästä. Ikäihmisten kohdalla tällaisen mahdollisuuden reiluus voi olla kyseenalainen: rohkenevatko kaikki halutessaan kieltää havainnoinnin? Kaikissa tapauksissa ei ole reilua edes laittaa potilasta tällaiseen valintatilanteeseen.
}

toteutetussa tapaustutkimuksessa kuvataan, miten vuorovaikutustaidot potilaan kohtaamisessa ilmenevät ja otetaan huomioon lääkäreiden hajautuskoulutuksen erilaisissa oppimisympäristöissä.

Havainnoinnin sijaan tai ohessa lääkäriopiskelijoiden osaamista ja sen kehittymistä on verraten tavallista tutkia myös itsearvioinnin avulla. Oman ammatillisen toiminnan itsearvioinnin voidaan ajatella kuuluvan olennaisena osana lääkärin ammatillista kompetenssia (52). Itsearviointi oman toiminnan reflektointia edellyttävänä menetelmänä voi parantaa ja syventää oppimista ja siten myös edistää ammatillisen kompetenssin kehittymistä. Oman edistymisen itsearviointi onkin tullut viime vuosikymmeninä kaikkeen koulutuksen perusasteelta korkea-asteelle. Itsearviointi ei ole helppoa ja sitä on arviointimenetelmänä kritisoitu perusteellisesti $(53,54)$. Erityisesti sen luotettavuus on kyseenalaistettu. Yksilöt eivät arvioi osaamistaan ja edistymistään samalla tavalla. Tutkimuksissa on esimerkiksi havaittu naisopiskelijoiden aliarvioivan ja miesopiskelijoiden yliarvioivan osaamistaan (55-57). Opinnoissaan hyvin menestyneillä on taipumus aliarvioida ja heikosti menestyneillä puolestaan yliarvioida suoriutumistaan työssä (58).

Vastaanotolle tulevien potilaiden haastatteluun tai kyselyyn perustuvan tutkimuksen ongelmana on ennen muuta potilaiden arviointikyvyssä. Eri ihmiset ovat tottuneet erilaisiin lääkäreihin, ja heidän vaativuustasonsa lääkäripalveluiden kuten muidenkin palveluiden suhteen vaihtelee. Potilaan arviot perustuvat kokemukseen, joka sinänsä on relevantti tutkimuksen kohde. Kokemus on tosi kokijalleen. Kokemukseen perustuva lääkärin kompetenssien analyyttinen erittely sen sijaan edellyttää luotettavan mittarin. Tällaisia mittareita onkin alettu kehittää juuri vuorovaikutus- ja kommunikointitaitojen arvioimiseksi (esim. 15-kohtainen Communication Assessment Tool) (59). Asiakaskyselyt yleistyvät terveydenhuollossa, kuten muuallakin palvelusektorilla. Mutta tutkijan suorittama havainnointi tai kollegan suorittama (vertais)arviointi tuottavat kompetensseista analyyttisempaa ja ammatillisen kehittymisen kannalta hyödyllisempää tietoa. Potilaskyselyt jäävät helposti asiakaskokemuksen kartoittamiseksi. 
Esimerkiksi havainnointiin verrattuna opiskelijoiden tuottamiin teksteihin perustuvalla tutkimuksella on monia etuja. Sillä saadaan kerättyä verraten vähällä vaivalla eräänlainen paneeliaineisto vakioidusta potilastapauksesta. Menetelmän ehkä suurin ongelma liittyy itse kirjoittamiseen: opiskelijoiden kirjalliset taidot, ja ylipäätään halu ilmaista itseään kirjallisesti, vaihtelevat. Kaikki tutkimukseen osallistuvat eivät paneudu yhtäläisellä vakavuudella tehtävänä olleeseen potilastapaukseen. Vastaamiseen ei liity palkkioita eikä sanktioita. Osallistumisvelvollisuuden saa täytettyä riippumatta vastauksen laadusta. Tämä on toki surveytutkimuksen yleinen ongelma. Mikäli tehtävä suoritettaisiin esimerkiksi osana tenttiä, vastaukset olisivat varmaan huolellisempia ja tarkemmin harkittuja. Mutta silloin vastaukset kertoisivat siitä, miten vastaajan mielestä pitäisi toimia, ei niinkään siitä, miten hän itse uskoisi toimivansa tilanteessa. Palkkioiden ja sanktioiden liittäminen tutkimukseen muuttaisi sen luonnetta olennaisesti ja vääristäisi saatua kuvaa.

Tässä tutkimuksessa esiin noussut lääkäriopiskelijoiden empatian väheneminen opintojen kuluessa vaatisi lisää tutkimusta. Onko itse koulutuksessa tai lääketieteen piilo-opetussuunnitelmassa jotain sellaista, joka johtaa empatian vähenemiseen? Millaista mallioppimista koulutuksen aikana tapahtuu? Vai onko kyse empatian vähenemisestä lainkaan? Ehkä se onkin kokemuksen vahvistamaa ammatillista varmuutta. Näin tulkittuna tutkimuksessa saadut tulokset kuvaavat lääkäriopiskelijan ammatillista kasvua: tapauskuvauksen aiheuttamat tunnereaktiot vähenevät ja ratkaisuhakuisuus vahvistuu.

\section{KIRJOITTAJIEN KONTRIBUUTIOT}

MS on toteuttanut aineiston analyysin ja kirjoittanut käsikirjoituksen ensimmäisen version. HS on ohjannut kokonaisuudessaan tutkimuksen toteutusta ja osallistunut artikkelin käsikirjoituksen muokkaamiseen. PK ja OV johtavat LeMextutkimushanketta, jonka aineistoa on käytetty tässä artikkelissa. PK ja OV ovat tukeneet tutkimuksen tekoa lääketieteelliseen koulutukseen liittyvällä erityisosaamisellaan. Kaikki kirjoittajat ovat osallistuneet tulosten tulkintaan ja käsikirjoitusluonnosten kommentointiin.

\section{Sundström M, Silvennoinen H, Kääpä P, Vainio 0. Practicing doctor- patient relationship - medical students interpretation on patient case during studies Sosiaalilääketieteellinen aikakauslehti - Journal of Social Medicine 2017:54: 134-150}

This qualitative longitudinal study analyzes how student construct doctor-patient relationship and interprets the same patient care in different phases during their studies. This study is part of a longitudinal follow-up study on medical education LeMex (Learning Medical Expertise). The research sample comprises students who began their education in 2006. The same sample of students was followed up over the period of their studies, and their progress was tracked by conducting annual evaluations during the years 2006-2012. Students were asked to resolve a short written patient case. Patient case assignments were analyzed by inductive content analysis. The results of the study show that on a professional level, communication skills got improved consistently during the education. Based on annual evaluations during studies, there was evidence of qualitative differences in how students approached the patient and close-relatives. Expressions of empathy decreased as the students proceeded in their studies. At the same time, students developed skills in making medical decisions about how to proceed with a case, as well as reach agreement with patient.

Keywords: Doctor-patient relationship, medical education, medical students, patient encounter 
(1) Pyörälä E. Reflektiivinen toimintatapa palautekeskustelussa-haaste lääkäreiden vuorovaikutuskoulutukselle. Pedaforum 2006;1:30-32.

(2) Gerlander M, Isotalus P. Professionaalisten viestintäsuhteiden ääriviivoja. Puhe ja kieli 2010; 30: 3-19.

(3) Sorjonen M-L. Lääkärin ohjeet. Kirjassa: Sorjonen M, Peräkylä A, Eskola K. (toim.) Keskustelu lääkärin vastaanotolla. Tampere: Vastapaino; 2001, 89-112.

(4) Cole SA. Reducing malpractice risk through more effective communication. Am J Manag Care 1997;3:649-653.

(5) Virshup B, Oppenberg A, Coleman M. Strategic risk management: reducing malpractice claims through more effective patient-doctor communication. Am J Med Qual 1999;14:153159. https://doi.org/10.1177/106286069901400402

(6) Flocke SA, Miller WL, Crabtree BF. Relationships between physician practice style, patient satisfaction, and attributes of primary care. J Fam Pract 2002;51:835-841.

(7) Silverman J, Kurtz SM, Draper J. Skills for communicating with patients. Radcliffe:Abingdon;2005.

(8) Wissow LS. Communication and malpractice claims - where are we now? Patient Educ Couns 2004;52:3-5.

https://doi.org/10.1016/j.pec.2003.11.004

(9) Reader TW, Flin R, Cuthbertson BH.

Communication skills and error in the intensive care unit. Curr Opin Crit Care 2007;13:732736. https://doi.org/10.1097/ MCC.0b013e3282f1bb0e

(10) Stewart MA. Effective physician-patient communication and health outcomes: a review. CMAJ 1995;152:1423-1433.

(11) Roter DL, Hall JA, Kern DE ym. Improving physicians' interviewing skills and reducing patients' emotional distress: a randomized clinical trial. Arch Intern Med 1995;155:18771884.

https://doi.org/10.1001/ archinte.1995.00430170071009

(12) Stewart M, Brown JB, Boon H ym. Evidence on patient-doctor communication. CDC 1999;3:25-30.

(13) Levinson W, Roter DL, Mullooly JP ym. Physician-patient communication: the relationship with malpractice claims among primary care physicians and surgeons. JAMA 1997;277:553-559. https://doi.org/10.1001/ jama.1997.03540310051034

(14) Makoul G. The interplay between education and research about patient-provider communication. Patient Educ Couns 2003;50:79-84.

(15) https://doi.org/10.1016/S0738-3991(03)00085-5

Ong L, De Haes J, Hoos A ym. Doctor-patient communication: A review of the literature. Soc Sci Med 1995;40:903-918.

https://doi.org/10.1016/02779536(94)00155-M

(16) Alroy G, Ber R, Kramer D. An evaluation of the short-term effects of an interpersonal skills course. Med Educ 1984;18:85-89. https://doi.org/10.1111/j.1365-2923.1984. tb00978.x

(17) Evans B, Sweet B, Coman G. Behavioural assessment of the effectiveness of a communication programme for medical students. Med Educ 1993;27:344-350. https://doi.org/10.1111/j.1365-2923.1993. tb00279.x

(18) Kendrick T, Freeling P. A communication skills course for preclinical students: evaluation of general practice based teaching using group methods. Med Educ 1993;27:211-217. https://doi.org/10.1111/j.1365-2923.1993. tb00259. $\mathrm{x}$

(19) Pyörälä E. Keskusteluanalyyttisen vuorovaikutustutkimuksen soveltaminen lääkärikoulutuksessa. Kirjassa: Sorjonen M, Peräkylä A, Eskola K. (toim.). Keskustelu lääkärin vastaanotolla. Tampere: Vastapaino; 2001,183-196.

(20) Maguire P, Pitceathly C. Key communication skills and how to acquire them. BMJ 2002;325:697-700. https://doi.org/10.1136/bmj.325.7366.697

(21) Fallowfield L, Jenkins V, Farewell V ym. Efficacy of a cancer research UK communication skills training model for oncologists: a randomized controlled trial. The Lancet 2002;359:650-656. https://doi.org/10.1016/S0140-6736(02)07810-8

(22) Fallowfield L, Jenkins V, Farewell V ym. Enduring impact of communication skills training: results of a 12-month follow-up. $\mathrm{Br} \mathrm{J}$ Cancer 2003;89:1445-1449. https://doi.org/10.1038/sj.bjc.6601309

(23) Berkhof M, van Rijssen H, Schellart A ym. Effective training strategies for teaching communication skills to physicians: An overview of systematic reviews. Patient Educ Couns 2011;84:152-162. https://doi.org/10.1016/j.pec.2010.06.010

(24) Pyörälä E, Hietanen P. Vuorovaikutustaidot osana lääkärin ammatillista kehittymistä. Suomen lääkärilehti 2011;66:469-474.

(25) Koponen J. Kokemukselliset oppimismenetelmät lääketieteen opiskelijoiden vuorovaikutuskoulutuksessa. Tampere: Tampere University Press; 2012.

(26) OKM. Koulutus ja tutkimus vuosina 20112016. Kehittämissuunnitelma. Opetus- ja kultturiministeriön julkaisuja. 1/2012. Luettu 14.1.2016.

http://www.minedu.fi/OPM/Julkaisut/2012/ liitteet/okm01.pdf?lang=fi 
(27) Patja K, Litmanen T, Helin-Salmivaara A. ym. Lääkärin ammatillisen osaamisen laajentaminen. Duodemic 2009;125:2365-2372.

(28) Kurtz SM, Silverman JD. The CalgaryCambridge Referenced Observation Guides: an aid to defining the curriculum and organizing the teaching in communication training programmes. Med Educ 1996;30:83-89. https://doi.org/10.1111/j.1365-2923.1996. tb00724.x

(29) Makoul G. The SEGUE Framework for teaching and assessing communication skills. Patient Educ Couns 2001;45:23-34. https://doi.org/10.1016/S07383991(01)00136-7

(30) Kalamazoo Consensus Statement 2001. Participants in the Bayer-Fetzer Conference on Physician-Patient Communication in Medical Education. Essential elements of communication in medical encounters: the Kalamazoo consensus statement. AAMC 2001;76:390-393.

(31) Kurtz S, Silverman J, Draper J. Teaching and learning communication skills in medicine. Radcliffe;Oxford:2005.

(32) Hargie O, Boohan M, McCoy M ym. Current trends in communication skills training in UK schools of medicine. Med Teach 2010;32:385391.

https://doi.org/10.3109/01421590903394603

(33) Novack D, Volk G, Drossman D. ym. Medical interviewing and interpersonal skills teaching in US medical schools: practice, problems and promise. JAMA 1993;269:2101-2105. https://doi.org/10.1001/ jama.1993.03500160071034

(34) Larochelle M, Bednarz N, Garrison J. (toim.) Constructivism and Education. Cambridge:Cambridge University Press; 2009.

(35) Tynjälä P. Oppiminen tiedon rakentamisena: konstruktivistisen oppimiskäsityksen perusteita. Helsinki:Kirjayhtymä; 1999.

(36) Taber K. Constructivism as Educational Theory: Contingency in Learning and Optimally Guided instruction. Kirjassa: Hassaskhah J. (toim.) Educational Theory. New York:Nova; 2011, 39-61.

(37) Malik S. Students, tutors and relationships: the ingredients of a successful support scheme. Med Educ 2000;34:635-641.

https://doi.org/10.1046/j.13652923.2000.00541.x

(38) Kalet A, Krackov S, Ray M. Mentoring for a new era. AAMC 2002;1171-1172.

(39) Kääpä P, Toivonen M, Koivisto A-L ym. Opettajalääkäri lääketieteen opiskelijoiden tukihenkilönä - kokemuksia opettajatuutoroinnista. Suomen Lääkärilehti 2012;67:1340-1344.

(40) Schouten B, Meeuwesen L. Cultural differences in medical communication: A review of the literature. Patient Educ Couns 2006;64:21-34. https://doi.org/10.1016/j.pec.2005.11.014
(41) Ruusuvuori J. Control in medical interaction. Practices of giving and receiving the reason for the visit in primary health care. Tampere:Acta Electronica Universitatis Tamperesis; 2000.

(42) Bethlehem J, Biffignandi S. Handbook of Web Surveys. New Jersey: John Wiley \& Sons; 2012.

(43) Fisher R, Katz J. Social-Desirability Bias and the Validity of Self-Reported Values. Psychology \& Marketing 2000;17:105-120. https://doi.org/10.1002/(SICI)15206793(200002)17:2<105::AIDMAR3>3.0.CO;2-9

(44) Nederhof, A. Methods of coping with social desirability bias: a review. EJSP 1985; 15:263280. https://doi.org/10.1002/ejsp.2420150303

(45) Ruohotie P. Oppiminen ja ammatillinen kasvu. Porvoo:Wsoy; 2002.

(46) Howe A. Professional development in undergraduate medical curricula - the key to the door of a new culture? Med Educ 2002;36:353-359. https://doi.org/10.1046/j.13652923.2002.01168.x

(47) Hojat M, Vergare M, Maxwell K ym. The Devil is in the third year: A longitudinal study of erosion of empathy in medical school. Acad Med 2009;84:1182-1190. https://doi.org/10.1097/ ACM.0b013e3181b17e55

(48) Levy A. Lääketieteen asiantuntijuus koulutuksen eri vaiheissa. Lääketieteen opiskelijoiden yleisorientaatiot, käsitykset hyvän lääkärin ominaisuuksista ja potilastyön hahmottumisesta. Tampere: Juvenes Print;2011.

(49) Haidet P, Dains JE, Paterniti DA, ym. Medical student attitudes toward the doctor-patient relationship. Med Educ 2002;36:568-574. https://doi.org/10.1046/j.13652923.2002.01233.x

(50) Tsimtsiou Z, Kerasidou O, Efstathiou N, ym. Medical students' attitudes toward patientcentred care: A longitudinal survey. Med Educ 2007;41:146-153. https://doi.org/10.1111/j.13652929.2006.02668.x

(51) Woloschuk W, Harasym PH, Temple W. Attitude change during medical school: A cohort study. Med Educ 2004;38:522-534. https://doi.org/10.1046/j.13652929.2004.01820.x

(52) Reiter HI, Eva KW, Hatala RM, ym. Self- and peer assessment in tutorials: application of a relativeranking model. Acad Med 2002;77:1134-1139. https://doi.org/10.1097/00001888-20021100000016

(53) Falchikov N, Boud D. Student Self-Assessment in Higher Education: A Meta-Analysis. RER 1989;59:395-430. https://doi.org/10.3102/00346543059004395

(54) Zell E, Krizan, Z. Do People Have Insight Into Their Abilities? A Metasynthesis. PPS 2014;9:111-125. https://doi.org/10.1177/1745691613518075 
(55) Lind DS, Rekkas S, Bui V, ym. Competencybased student self-assessment on a surgery rotation. J Surg Res 2002;105:31-34. https://doi.org/10.1006/jsre.2002.6442

(56) Rees C. Self-assessment scores and gender. Med Educ 2003;37:572-573. https://doi.org/10.1046/j.13652923.2003.01545.x

(57) Rees C, Shepherd M. Students' and assessors' attitudes towards students' self-assessment of their personal and professional behaviours. Med Educ 2005;39:30-39.

https://doi.org/10.1111/j.13652929.2004.02030.x

(58) Edwards RK, Kellner KR, Sistrom CL, ym. Medical student self-assessment of performance on an obstetrics and gynecology clerkship. Am J Obstet Gynecol 2003;188:1078-1082. https://doi.org/10.1067/mob.2003.249

(59) Makoul G, Krupat E, Chang CH. Measuring patient views of physician communication skills: Development and testing of the Communication Assessment Tool. Patient Educ Couns 2007;67;333-342.

https://doi.org/10.1016/j.pec.2007.05.005
MARI SUNDSTRÖM

KM, Tohtorikoulutettava

Turun Yliopisto

Kasvatustieteiden laitos

Heikki Silvennoinen

Professori

Turun yliopisto

Kasvatustieteiden laitos

PEKKA KäÄPÄ

Emeritusprofessori

Turun yliopisto

Lääketieteellinen tiedekunta

Olli Vainio

Professori

Oulun yliopisto ja Oulun yliopistollinen sairaala Biolääketieteen ja MRC Oulu tutkimusyksiköt Nordlab Oulu 